\title{
Radikal Hayalciler/Kadınlar \\ Radical Daydreamers/Women
}

Handan Çelikci*

Sheila Rowbotham, Yeni Bir Çă̆ Hayali-Yirminci Yüzyılı Yaratan Kadinlar, Çev. Suğra Öncü, İstanbul: Sel Yayıncılık, 2013, 359 s.

Yeni Bir Çăg Hayali isimli kitap Sheila Rowbotham tarafindan 2010 yılında İngilizce olarak yazılmış, Suğra Öncü tarafından Türkçeye çevrilmiş ve Sel Yayıncılık tarafindan 2013 yılında yayımlanmıştır. Kitap, 359 sayfa ve 10 bölümden oluşmakta, her bölümde kadınların sanayileşme sürecini takip eden dönemde hak ve kazanımları için yaptıkları mücadeleler İngiltere ve Amerika çerçevesinde anlatılmaktadır. Kitap aynı zamanda dönemin kadınlarıyla ilgili fotoğraflara da yer vermektedir.

Yazar, XIX.yy'ın tüm alanlarda değişim yaşanan bir yüzyıl olduğunu ve kadınların da bu değişimden olumlu etkileneceklerine inandığını belirterek "Gündelik yaşam ve kültürün yanı sıra kendi yazgılarını da değiştirmeye çabalayan kadınlar hem hayalci hem maceracıydılar, çünkü en kabataslak haritalardan yararlanarak keşfe çıktılar ve bilinmeyene doğru yola çıkarak kişisel ilişkilerde ve toplumda öngörülen davranışları cesurca sorguladılar.” (s.11) ifadesiyle kadın hareketleri hakkındaki düşüncesini özetlemektedir.

Eserin, 'Gündelik Yaşam Maceraları' başlığında kadınların XIX. yy içinde gündelik hayatta birçok alanda hak kazandıklarından bahsedilmektedir. Amerika ve İngiltere'de ekonomide yaşanan

* Sosyolog, e-mail:h.clikci@gmail.com 
değişimler sonucunda yasal düzenlemelerin yapıldığı ve kadınların da bu düzenlemelerde yer almasıyla bazı alanlarda çalışma hakkı kazandıkları anlatılmaktadır. İşçi sınıfının hak kazanımı konusunda başlattığı hareket, kadınların toplumsal alanda hak kazanımında etkili olmuştur. Bu noktada işçi sınıfının kadınların kamusal alanlardan yararlanması için onları destekledikleri belirtilmektedir. Yazar bu dönemdeki aktivist kadınların, gündelik yaşama toplumsal cinsiyet merceğinden bakarak erkek deneyimlerinin evrensel kabul edilmesini eleştirdiklerini ifade eder. Kadınların bu bağlamda kendi çalışma koşullarını iyileştirmek için sınıflar arası örgütler kurmaya yöneldiklerini aktarır. Nitekim 1874'te Kadın Sendika Birliği kurulmuştur. Bu örgütlenmelerin Hıristiyan örgütlenmelerden destek aldığı belirtilmektedir. Yazar, kadın örgütlenmesinde Hıristiyan hayırsever örgütlerinin kadınların topluma ulaşmasında etkisini tekraren söylemekte ve kadın maceracıların alt sınıftan mahallelere ilk başta bu yolla ulaştıklarını anlatmaktadır.

Rowbotham, kadın hareketlerinin başlangıçta içki karşıtı ve Hıristiyan kadın birlikleriyle hareket ettiğini ancak 1890'larda doğum kontrolünü, cinsel özgürlüğü, evlenmeden çocuk doğurmayı, kadınlara âşık olma özgürlüğünü savunan kadın dergilerinin de görünür hale geldiğini ifade etmiştir. Bu durum ilerleyen dönemlerde kadın hareketinin ayrışmasının ve tek bir hareket haline gelemeyişinin başlıca nedenleri arasındadır. Rowbotham, yine bu süreçte kadın hareketlerinin, toplumdaki ekonomik ve ırksal eşitsizliklere de karşı çıktığını söyleyerek sınıfsal mücadeleyle kadın hareketinin kesişen noktalarına vurgu yapmıştır. Ayrıca, İngiltere ve Amerika'da gelişen kapitalist ekonomiye karşı oluşan, sol ve komün tepkilerinin yarattığı değişimle kadın hareketlerinin paralel geliştiğini ifade etmiştir. Kadın hareketinin modern dönemin getirdiği yeniliklerle dönüştüğü, dolayısıyla kadınların isteklerinin bireysel özgürlüklerinin çoğaltılması noktasında olduğu anlaşılmaktadır.

“Günlük Yaşam Maceraları” başlıklı bölümde kadın hareketi öncülerinin işçi sınıfını yakından takip ederek kadınları örgütlemeye çalıştıkları anlatılmaktadır. Kadın hareketinin çoğu öncüsünün, 
aslında toplumun ekonomik düzeyi yüksek kesimine mensup olması dikkat çekicidir. Bilfiil işçi olmadıkları halde bu topluluklara dâhil olarak iş̧̧i kadınları yönlendirdikleri anlaşılmaktadır. Yazar, kadın öncülerin kendilerinden vazgeçerek fedakârca mücadele ettiğini belirtmektedir. Bazılarının Hıristiyan düşünceyle, bazılarının komünist ideolojiyle beslendiği iddia edilmektedir. Bunun yanında Feminist kadınların yoksulların arasına karışmanın onlar için çok yararlı olduğunu söylemeleri; kadın hareketinin toplumun üst sınıfı tarafından oluşturulduğu, halkın doğal tepkisi olarak gelişmediğini ortaya koymaktadır. Bu bölümde kadınların farklı toplumsal muhalif hareketlerde yer aldıkları aktarılmış; Darwinci düşüncenin ve Marksist ideolojinin etkisiyle modern problemlerin yanında yerleşik Hıristiyan kültürünün kadın erkek algısına karşı da tepkilerin geliştiği belirtilmiştir. Aynı zamanda o dönemki kadın hareketlerinin düzenli ve belirlenmiş hedeflere göre hareket eden bir yapıdan uzak oldukları vurgulanmıştır. Cinselliğin serbestliği ve lezbiyen kimliğinin konuşulmasının da kadın maceracıların mücadeleleriyle söz konusu olduğunu iddia etmiştir.

1.Dünya Savaşı döneminin ağır etkisi; feminist yazar Ford'un Eşik isimli romanında yazdığı gibi (XX.) "yüzyılın değişimin eşiğinde oluşu" (s.53) ikinci bölümde "Nasıl Olmalı?" başlığıyla ele alınmıştır. Bu bölümde kadınların kıyafetleri, yaşam şekilleri ile kamusal alan ve özel hayatı tartıştıkları anlatılmaktadır. Kadınların geleneklerden kurtulması "giysi toplumsal bir kumaştandır; bir toplumsal deridir" cümlesiyle özetlenmektedir. 'Kişisel mahremiyetin ve cinsel arzuların toplumsal ve politik kamu alanına yansitılması kadın özgürlüğünün en zor yanlarından biri oldu' ifadeleri ile yazar kadın bedeninin feminist aktivizm içinde ele alınışını değerlendirmiştir.

Kitabın 'Cinsellik Sorunu' bölümünde Rowbotham'a göre cinselliğin kadınlar tarafindan konuşulması ve metinlerde yer alması mahrem olarak nitelenen bir konunun bu yolla kamusal alana taşınması ve görünür hale gelmesi açısından önemlidir. Kendinin 
sahibi olma, özgür aşkçlar, dianacılık ${ }^{1}$ konularının kadınlar arasında konuşulduğu, kadın dergilerinde tartışıldığı anlatılmaktadır. Tartışmada kullanılacak dilin nasıl olacağı, argo dilinin cinsel konuları anlatma noktasında kelime sıkıntısı çekmemesine rağmen seviyeli bir dilde yeterli kelime olmadığı bile söylenmiş ve bu durumun "her çeşit insan için her çeşit ilişki" olarak ifade edildiği belirtilmiştir (s.106).

Rowbotham 'Her Genç Kızın Bilmesi Gerekenler' başlıklı bölümde, kadınların kendilerini ifade etmelerinde serbest ve rahat bir dil kullanmaları; kadının cinsel özgürlük, doğum kontrolü, üreme özgürlüğü gibi konuları konuşma ve tartışmasında kabul görmüş bir dilin kullanılması noktalarına vurgu yapmıştır. Öte yandan, XX.yy'da kadınların anne olma zamanını kendilerinin tayin etmek istemesi ve öjenikler ${ }^{2}$ sebebiyle üreme özgürlüğü ve doğum kontrolü gibi meseleler gündeme gelmiştir. Yazar, kadının çocuğa ayırdığı zamanını okumak, düşünmek ve gelişmek için gerekli olan zamandan çaldığını savunan kadınların, özgürlük için zamana ihtiyaç duyduklarını vurgulayarak gündem oluşturmaya çabaladıklarını belirtmektedir.

Kitabın, 'Annelik' başlıklı bölümünde çocuk doğurmanın madende çalışmaktan kat kat tehlikeli olduğu ifade edilirken, bu dönemde aynı zamanda kadınların eğitimli anne olmasının gerekliliğine işaret edildiği anlatılmaktadır. 1920’lerde yaşam tarzlarının değişmesiyle birlikte teknolojik aletlerin kullanılmasının, yeni tarzda evlerin oluşturulmasının, kadınların ev ekonomisi, ev idaresi öğrenmelerinin, kadın çocuk sağlığı merkezlerinin açılmasının gerekliliği aktarılmaktadır. Kadınların çok düşük ücretlerle çalışmasının onları fahişeliğe ittiğini belirten yazar, İncil basımı yapan matbaalarda çalışan kadınların, daha düşük ve daha kötü ücretlerle çalıştığını belirterek kadının karşı karşıya kaldığı ironik durumu ortaya

1 Dianacılık: Cinsel birleşme içermeyen bir aşk yaşantısı.

2 Öjenik: İlk kullanım Eflatun'a kadar gitse de, modern anlamıyla ilk olarak Sir Francis Galton tarafından ortaya atılmış, sağlıksız ceninleri ayırıp, sağlıklı ceninler yetiştirmenin yollarını arayan, bilimselliği tartışmalı bir toplumsal akım veya toplumsal felsefedir. 
koymaktadır. Bununla birlikte bazı kadınların çocuklarına annelik yapamadıkları için üzgün olduğu, kadınların duygusal anlamda sorun yaşadıkları da vurgulanmaktadır. Yaşamın demokratikleşmesiyle kadın haklarının gelişmesi arasındaki paralelliğin anlatılmasıyla son bulan kitap, kadınların hak arayış süreçleri ve kadın hareketleri ile ilgili araştırmalar açısından kaynak kapsamında değerlendirilebilir. Rowbotham, XIX.yy kadın hareketini "Kadınların özerklik hamlesindeki aykırılıklar daha çok başkaldırıya yol açtı; artan sayıda orta sınıf kadını bir ayağının geleneksel dünyada öbürünün keşfedilmemiş 'yeni kadınlık' alanında olduğunu gördü. Sınıfların ve toplumsal cinsiyetin çizili sınırları arasında gidip gelen bu 'tuhaf kadınlar' ortaya çıkınca yerleşik düzen sarsıldı: Toplumun kurulu yapısına uymuyorlardı ve gariplikleri muhalif kalmalarına sebep oldu." (s.37) ifadeleriyle özetlerken, dönemin İngiltere'sindeki okullara kadınların girmelerinin yasak olması nedeniyle, kitap almaya erkek yardımcıları gönderdiklerini; vasıflarını geliştirseler dahi kadınların istihdamda arka plana atıldıklarını vurgulamıştır.

Kitap, kadın hareketinin tarihî serüvenine kuşbakışı bir yaklaşımla kadın çalışmalarına başlık olarak yer veriyor denilebilir. Bu durum kadın çalışmalarıyla ilgili araştırma yapacaklar için isim, dergi ve kaynak bulma noktasında kitabı önemli kılıyor. XIX.yy'da yaşanan iş̧̧i hareketlerinin ve iş̧̧i hareketleriyle sol söylem arasındaki ilişkinin kadın hareketlerinin gelişiminde etkili olduğu anlaşılıyor. Kitap boyunca kadın özgürlük hareketinin geleneksel anlayışla mücadele ederken kendi aralarında da fikir ayrılığına düştükleri, kadının anne olması, çalışması, toplumsal hayata erkekle eşit oranda katılması gibi konuların farklı değerlendirildiği anlatılıyor. Kitabın içeriğinde yer alan 150 yıl önce tartışılan konuların bugün hâlâ konuşuluyor ve çoğunda pek fazla değişim sağlanamamış olması dikkat çekici görünüyor.

Kitabın kadın hareketlerini anlatırken meselenin alt yapısından söz etmemesi, konunun okuyucu zihninde oturmasını zorlaştırdığı söylenebilir. Kitabı okurken kadın hareketlerindeki bazı feminist yazarların ve aydınların adeta sıkıldıkları bohem hayatlarında 
bir macera ararmış edasıyla bu hareketlere katıldıkları izlenimi oluşuyor ve okuyucuda ütopik bir işin peşine düşüldüğü hissi uyanıyor. Kitapta dikkat çeken noktalardan biri de kadınların o dönemdeki tartışmalarının, cesur ve radikal bir tarzda olmasıdır. Kadınların söylemlerinin oldukça dar ve belirli çevrelerde konuşulan konular olduğu anlaşılmakla beraber, kadınların başlattıkları eylemlerde toplumsallaşan söylemlerin daha çok kadınların yoksulluğuyla ilgili ücretsiz hizmet anlayışlarının olduğu ortaya çıkmaktadır. Kadınların cinsel özgürlük söylemleri yanında bağlılık duygularının da tartışma konusu olduğu görülüyor. Tüm bunlar kadınla ilgili hareketlerin ve kadına yönelik çalışmaların çok boyutlu olduğunu ortaya koymaktadir.

Yazarın kadın hareketinin tarihsel seyrini anlatırken öne ç1kan farklı isimlerden ardı ardına söz etmesi ve aktarılan gelişmelerin birbirini takip etmemesi çalışmanın akıcılığını azaltan bir etken olarak karşımıza çıkmaktadır. Yazarın anlattığı tarihî seyirde, İngiltere ve Amerika arasında gidip gelmesi de okuyucunun olayları birleştirmesini ve asıl vurgunun öne çıkmasını zorlaştırmaktadır. Ayrıca paragraflar arasında bütünlük kurmanın zorluğu ve konunun parça parça aktarılması okuyucunun kitabı okurken akıcılığı yakalamasını zorlaştırıyor. Bu durum içerikten alınan verimi azaltıyor. Tüm bunların yanında Türkiye'de, dünyada kadın hareketleriyle ilgili kaynak çalışmalarının azlığı dikkate alındığında kitabın literatürdeki önemi yadsınamaz. 